\title{
Contributors
}

\section{Robyn Cadwallader}

Robyn Cadwallader is a writer and editor who lives in the country outside Canberra. She has published poems, prize-winning short stories and reviews, a non-fiction book about virginity and female agency in the Middle Ages (2008), a poetry collection, $i$ painted unafraid (2010), and an edited collection of essays on asylum seeker policy, We Are Better Than This (2015). Her first novel, The Anchoress (2015) won a Canberra Critics Award and was shortlisted for the Indie Book Awards and the Adelaide Festival Literary Awards.

\section{Carla Daws}

Carla Daws is Team Leader, Information Services (Wagga Wagga and Albury campuses) at Charles Sturt University. Carla has been based at the university for six years, starting as a Cataloguing Librarian, and then moving into teaching undergraduate students information literacy.

\section{Evelyn Eveni}

Evelyn Eveni is in her second year as the Librarian at the Kanana Fou Theological Seminary in Pago Pago, American Samoa. The library was built in 2008 to commemorate the $25^{\text {th }}$ anniversary of the Seminary. Evelyn assists staff and students of the Seminary in their research. She has also initiated a project recovering, preserving and shelving thousands of new textbooks.

\section{Michael Gladwin}

Michael Gladwin is Lecturer in History at St Mark's National Theological Centre in the School of Theology, Charles Sturt University, Canberra. A graduate of the Australian National University and the University of Cambridge, his research interests include the religious and cultural history of Australia and the British Empire, with a particular interest in the relationship between religion and war in Australian history. Michael is the author of Captains of the Soul: A History of Australian Army Chaplains (2013) and Anglican Clergy in Australia. Michael won the Australian Christian Book of the Year 2015 for this work. His latest publication is 1788-1850: Building a British World (2015). He is also editor of St Mark's Review, one of Australia's longest-running theological journals. His current research projects include an edited monograph on the history of preaching in Australia, a chapter on the 
intellectual history of mission and colonialism during the long nineteenth century for the forthcoming Oxford Handbook of Nineteenth-Century Christian thought, and The Place of Religion in Australian War Commemoration Since 1914.

\section{Mark Hangartner}

Mark has been a Subject Librarian at University of Auckland for 20 years, currently English and European Languages as well as Theological and Religious Studies. In the last 12 months one of the Library's big projects has been to introduce an automated course readings system and Mark has been involved with 45 courses introducing new reading lists. Mark's role includes helping Academics and postgraduate students with their research and undergraduates too. This involves one-on-one consultations, teaching RefWorks and Literature review courses.

\section{Sue Lavery}

Sue Lavery is a Queenslander by birth, (and inclination,) but has lived in Canberra for the past 23 years. She only ever wanted to teach, and achieved that in 1974. After a career as a teacher and then as a teacher librarian teaching at all levels and in both public and Private schools in Queensland, Victoria and ACT, for over 30 years, Sue decided to take a great leap and left to set up the Alexander Maconochie Centre Library. Although she had enjoyed teaching and life as a teacher librarian, this last position was the most intriguing, rewarding and interesting job of her career. Sue was part of the ALIA Prison Library Guidelines Working Group that developed the revised guidelines. The revised guidelines were published in December 2015, Australian Library and Information Association Minimum Standard Guidelines for Library Services to Prisoners. Sue is now retired - a little reluctantly- but retains her interest in reading, the Justice system and the part Libraries play in society.

\section{Fiona Pfennigworth}

Fiona is currently researching the theology and literary features of the book of Psalms, and exploring visual concepts and Australian habitats that may reflect it. From this research she hopes to produce The Psalms Illuminated, her third volume of biblical books in which illustrations of Australian nature are in conversation with the text. The Scrolls Illuminated: An Illuminated Presentation of Solomon's Song of Songs, Ruth, Lamentations, Ecclesiastes and Esther from the Bible Fiona self-published in 2011, the product of her $\mathrm{PhD}$ in Natural History Illustration at the University of Newcastle. John Illuminated was self-published in 2014, the product of her Masters in Theology (Hons) at Charles Sturt University. Fiona has been a casual lecturer at the University of Newcastle; exhibiting artist; home mother-of-two; journalist; layout artist; cook; law clerk; and lover of the Scriptures, amongst other things. 


\section{Trevor Schaefer}

Trevor finds pleasure working amongst like-minded and amiable colleagues, in a quiet, busy environment. He enjoys helping students in their search for information on their latest assignment. He finds it a pleasure to help people track down that vital piece of information on some obscure topic that really matters to them. And when Trevor takes work home, it is in the form of a good book to read, because after all, he cannot read on the job! Trevor's publications include: Fish out of Water, XLibris, 2015 Luther Bible 1551, ALC, 2015 Glimpses: Anthology, Tea Tree Gully Library Writers Group, 2014 The Light on the Hill: Brougham Place Uniting Church 1859-2009, BPUC, 2009, St Mark's Lutheran Church, Mt. Barker: A Venture of Faith, 1958-1983, 1983 The Treatment of Germans in SA 1914-1924, Thesis, 1982.

\section{Maria Stanton}

Maria Stanton, Director of Digital Production, has strategic responsibility for ATLA's full product line, including ATLA Religion Database with ATLA Serials. ATLA's growth in recent years is the result of an intentional commitment to expanded global relationships, including our collaboration with similar associations in other regions of the world and the creation of programs to support researchers in developing countries. Maria is also a member of ATLA's leadership team. Prior to joining ATLA, Maria was the VP of Production for Alexander Street Press.

\section{Uesile (Wesley) Tupu}

Rev. Uesile Tupu is an ordained minister of the Methodist Church in Samoa and Lecturer in Theology and Ethics at Piula Theological College since 2013. He has a Diploma in Theology, Bachelor of Divinity and Masters of Theology. Uesile has research interests in theological hermeneutics, contextual theology and Christian ethics.

\section{Helena Zobec}

Helena's background has included working across a number of libraries with a strong emphasis in tertiary libraries, including the Canberra Institute of Technology, University of Canberra and the Australian National University. She has also worked for the Public and National Libraries in the ACT. Helena has a long history of lobbying for the recognition of information literacy as an employability skill, leading the TAFE Library sector to formally recognize these skills. Helena is currently employed as the Campus Library Manager, Signadou Library, ACU. As part of that role since her appointment, the New Library Building has been a priority Project undertaken as a staged process during this period with an estimated completion date of 2017. 